\title{
セダムの生育に及ぼす土㙥水分と照度の影響
}

\section{Effect of Soil Moisture and Light Intensity on the Growth of Sedum}

\author{
飯島健太郎 ${ }^{*}$ 近藤三雄 ${ }^{*}$ \\ Kentaro IIJIMA Mitsuo KONDO
}

\begin{abstract}
摘要 : セダム属 3 種の生育に影響を及ぼす照度と土㙗水分の関係について検討した。いずれも相対照 度 30\%以上で生育が良好であった。特にメキシコマンネングサの生体重量は相対照度 $30 \%$ では直射 光の 2 倍となり，生育量が大きくなるのは遮光条件であったが，直射光下よりも葉が薄くなり耐乾性 が㯺念された。相対照度 7\%ではマルバマンネングサ, メキシコマンネングサは僅かに生育したが, タイトゴメは衰退し耐阮性に劣った。次にメキシコマンネングサは人工光の照度 20 3Kluxで良好 に生育し，マルバマンネングサは 20 1Klux で比較的良好に生育したが，0.5Klux では湿潤条件で衰 退、乾燥条件では僅かな生育を示すなど低照度では乾燥条件の場合には生育低下の度合が小さくなる 傾向が認められた。
\end{abstract}

\section{1. 研究目的}

Sedum 類の導入が最も期待されている空間は，すでにドィッ で先進的に行われている超薄層・軽量基盤による緑化屋根1,7) であ る。Sedum 類が極めて僅かな培地で生育が可能であること や 無給水状態におかれても長期間の生存が可能であり ${ }^{3)}$ 耐乾性に優 れることがその理由である。近年の緑化空間の多様化，例えば壁 面緑化への導入が拡大するなかで，十分な照度が得られない場所 での利用可能性が問われるようになってきたが, 関連の研究デー 夕が不足しているのが現状である。わが国では従来, Sedum 類 は公園緑地の地被材料としての活用が一般的であり, 陽光地だけ ではなく樹木の根締めや棟間空地などの低照度空間への利用も見 られるが，一時的に旺盛な生育を示すものの急激に衰退したり， 一方では旺盛な生育は示さないもののコンパクトに生育を持続し ている場合もあり, 生育に及ぼす照度条件の影響は大きいもの之 考えられる。特に草丈の高い雑草が侵入すると，その場所から Sedum が消失する現象が見られたり, 筆者らの調査においても 自生地のタイトゴメ（Sedum oryzifolium）の分布は照度条件 との関係があることを指摘した ${ }^{8)}$ 。Sedum 類の多くが日光の照 りつける山地や海岸の岩盤面などを自生地としていることから， 低照度条件に対しては適応性に乏しいと考えられているが，養父 ら ${ }^{12)}$ はマルバマンネングサ（S. makinoi），ッルマンネングサ (S. sarmentosum), メキシコマンネングサ (S. mexicanum) が，白色蛍光灯を光源とした $1 \mathrm{~K} l u x$ 程度の低照度条件下で生育 可能であることを実験的に示している。また筆者ら ${ }^{5)}$ は関連した 研究で気温と土壌水分の組合せによるメキシコマンネングサの生 育反応について検討した結果, 生育が比較的良好なのは, 湿潤 （土壌含水率 $50 \%$ ）で低温条件（明 /暗期気温 $15 / 10^{\circ} \mathrm{C}$ ）であり, 土壌が湿潤で高温条件 $\left(30 / 25^{\circ} \mathrm{C}\right)$ であると生育が衰退したが, 乾燥条件（土壤含水率 $25 \%$, 永久しおれ点相当）の場合には, 高温条件での衰退は抑制され，土㙵水分条件之の関係が大きく影 響することを指摘している。そこで低照度条件下での生育につい てむ土壌水分条件との関係から検討する必要があると考えられる。 一方, 以上のような生育量からみた場合の生育と乾燥耐性に富む 形状の生育が，両立するかということも疑問である。

そこで本研究では, Sedum の生育ならびに形状に及ぼす照度 の影響, さらに土壌水分条件との関連, 種類による生育反応の差 異について究明することを目的として実験を行った。

\section{2. 実験材料と方法}

前述の目的のために11屋外における相対照度（4 段階）と水分 の供給度合を変えることを意図した土㙵量の違い（2 段階）によ るセダムの生育について, (2)人工光における照度 (4 段階) と土 壤水分条件の違い（2 段階）によるセダムの生育反応について, 2 通りの実験を行い生育反応を探った。

(1) 屋外における相対照度と土壤量の違いによるセダムの生育

供試植物は神奈川県横浜市内で採取したマルバマンネングサ (山地性), メキシコマンネングサ (帰化種), 江の島で採取した タイトゴメ (海岸性) とした。2 $3 \mathrm{~cm}$ の茎長に調整した挿し穂 の生体重量を計測後, 1997 年 6 月 20 日に容量の異なる 2 通りの 容器, すなわち $\phi 115 \mathrm{~mm} \times \mathrm{h} 70 \mathrm{~mm}$ (NEUBAUER'S POT を使用。 以下，刘照土壌区）と $\phi 30 \mathrm{~mm} \times \mathrm{h} 50 \mathrm{~mm}$ （以下，土壇量制限区）に 砂土（粗砂 $88.55 \%$, 細砂 $10.97 \%$, シルト十粘土 $0.48 \%$, 土性 S：国際法）を充填し1ポット当たり 3 芽を挿し芽した。それか ら 2 週間後の 7 月 5 日各照度条件下（無遮光区, 相対照度 30 ,

$7,3 \%$ の 区）に設置し, 対照土壤区は 3 反復, 土壤量制限区 は 5 反復で実験を行った。実験期間中，降雨による給水を基本と し， 2 週間以上降雨がなかった場合には灌水を行った。

生育状態の計測は同年 8 月 11 日, 12 月 24 日，1998 年 4 月 30 日, 8 月 1 日に葉数, 葉厚, 茎数, 茎長, 節間長について行い, 最後に生体重量, 乾燥重量の計測を行った。

\section{（2）人工光における照度と土壤水分の臮いによるセダムの生育}

供試植物は前項の実験で耐陰性の劣ったタイトゴメを除き，前 項同様の採取地で入手したマルバマンネングサ, メキシコマンネン グサの 2 種とした。 $2 \sim 3 \mathrm{~cm}$ の茎長に調整した挿し穂の生体重量 を計測後，1996 年 3 月 13 日に 1 ポット当たり 3 芽を挿し芽した。 ポットはNEUBAUER'S POT を用い，排水層として発砲棟石 を $100 \mathrm{~g}$ ，その上に黒ぼく土の下層土（ $5 \mathrm{~mm}$ 目のふるいを通過）を $300 \mathrm{~g}$ 充填したものを用いた。約 40 日間ガラス温室内で養生し， 同年 4 月 23 日にメタルハライドランプを光源とする人工光グロー スキャビネット（明 /暗期気温 : $25 / 20^{\circ} \mathrm{C}$, 照度約 $20 \mathrm{Klux}$, 設 定湿度 65\%) に移動し養生を継続した。同年 6 月 5 日に供試材料 の葉数, 茎長を計測した後, 各照度区に般入し実験を開始した。 実験は 3 反復で行った。照度条件として 20Klux（22.666士0.478 Klux, $\left.440.57 \pm 3.16 \mu \mathrm{mol} \cdot \mathrm{m}^{-2} \cdot \mathrm{S}^{-1}\right)$ に対して, 遮光枠を用い $\tau 3 \mathrm{Klux}\left(3.130 \pm 0.203 \mathrm{Klux}, 67.91 \pm 2.37 \mu \mathrm{mol} \cdot \mathrm{m}^{-2} \cdot \mathrm{S}^{-1}\right)$, 
1Klux $\left(1.044 \pm 0.025 \mathrm{Klux}, 20.79 \pm 2.54 \mu \mathrm{mol} \cdot \mathrm{m}^{-2} \cdot \mathrm{S}^{-1}\right)$ ，およ び 0.5Klux $\left(0.488 \pm 0.054 \mathrm{Klux}, 10.58 \pm 1.68 \mu \mathrm{mol} \cdot \mathrm{m}^{-2} \cdot \mathrm{S}^{-1}\right)$ の 4 区に設定した。照射時間は 1 日あたり 12 時間とした。各照度 区において土㙵水分条件を飽和容水量に近い湿潤状態（0〜 - 0.0 $5 \mathrm{MPa}$ ） と永久しおれ点付近の乾燥状態（約 $-1.5 \mathrm{MPa}$ ）とする ために土壤含水率を $50 \% ， 25 \%$ の 2 段階に設定した。含水率の設 定方法としては供試した土埕の含水率に対する水ポテンシャル値 を計測して関係曲線を作成し, それを基に目標水分条件となる実 験ポットの総重量を計算した ${ }^{5)}$ 。土㙋水分の調節は，実験開始後 $3 \sim 5$ 日に 1 回ポットの重量を秤量し, 減少した重量相当分の水 分を各々のポットに給水して行った。

生育状態の計測は, 実験開始から 3 か月後に生体重量, 乾燥重 量 (地上部, 地下部), 葉数, 茎長, 葉厚について行った。葉厚 の測定は, Dial thickness gauge を用いて葉身の中央部を計測 し, 各区 3 個体 9 葉位の測定をした。

\section{3. 実験結果ならびに考察}

（1）屋外における相対照度と土壤量の違いによるセダムの生育

(i ) 実験終了時の重量 (表-1)

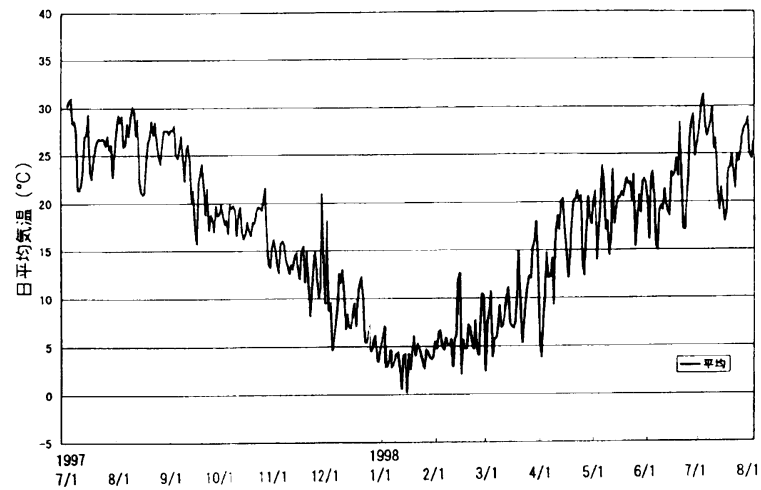

図-1 実験期間中の気温の変化（日平均気温）
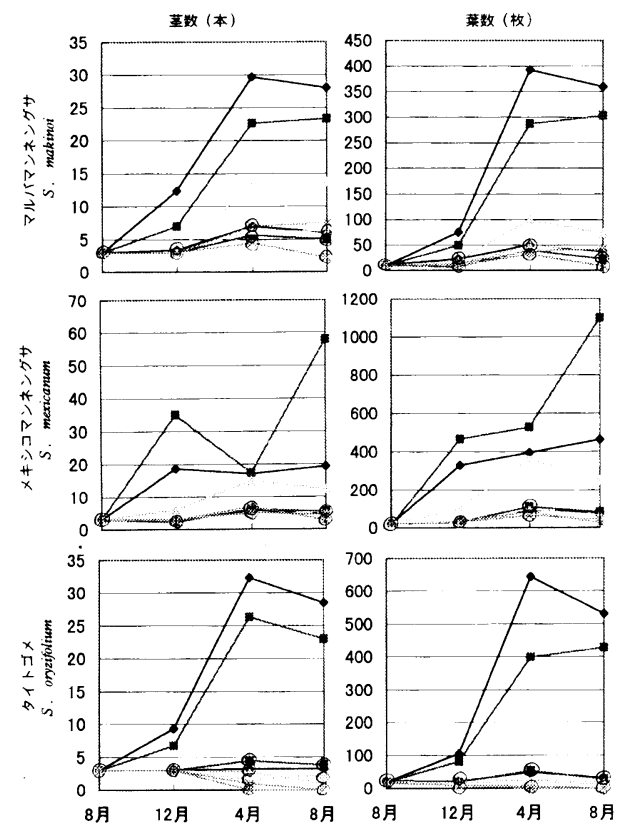

図ー2相対照度と土壇量の異なる条件下で生育した Sedum 類 3 種の茎数, 葉数の変化

注）測定值は, 対照土壇区は 3 ポットの平均値, 土壤

量制限区は 5 ポットの平均値を示す。

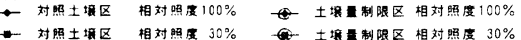

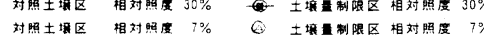

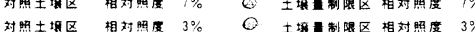

マルバマンネングサの実験開始時から実験終了時までの生体重 量の増加比は, 無遮光区と相対照度 30\%区ではほぼ同様で, 対 照土壤区では約 45 , 土㙲量制限区では 3 , 相対照度 $7 \%$ 区では 対照土壤区では約 10 , 土壌量制限区で 3 とやや生長が劣った。 相対照度 $3 \%$ 区になると生体重量が実験開始時の $1 / 5$ に減少し, 衰退する傾向にあった。

メキシコマンネングサの生体重量の増加比は, 無遮光区では対 照土壤区の 31.05 , 土壤量制限区の 1.4 に比較して, 相対照度 30 \%区では対照土壌区 56.53 , 土裹量制限区区 4.88 となり，むしろ 無遮光区に比べて生育が良好であった。相対照度 $7 \%$ 区では対照 土壤区 5.04 , 土㙵量制限区 2.18 となり, やや生育が劣った。相 対照度 $3 \%$ 区では生体重量は減少し衰退する傾向であったが, 対 照土壤区の方が土㗧量制限区に比較して減少度合が大きく, 土壌

表 -1 照度と土壤容積の組合わせによる各種 Sedum の生育量

\begin{tabular}{|c|c|c|c|c|c|c|c|c|c|c|}
\hline \multirow{2}{*}{$\begin{array}{c}\text { 草種 } \\
\text { (学名) }\end{array}$} & \multirow{2}{*}{$\begin{array}{l}\text { 相対 } \\
\text { 照度 }(\%)\end{array}$} & \multirow{2}{*}{$\begin{array}{l}\text { 土壤 } \\
\text { 谷樍 }\end{array}$} & \multicolumn{4}{|c|}{ 生体重量(g) } & \multicolumn{4}{|c|}{ 乾燥重量(g) } \\
\hline & & & \multirow{2}{*}{$\begin{array}{l}\text { 地上 } \\
14.88 \mathrm{a}\end{array}$} & \multirow{2}{*}{$\frac{\text { 地下 }}{1.24}$} & \multirow{2}{*}{$\frac{\text { 全体 }}{16.12}$} & \multirow{2}{*}{$\begin{array}{l}\text { 增加比 } \\
48.61\end{array}$} & \multirow{2}{*}{$\frac{\text { 地上 }}{1.16 \mathrm{a}}$} & \multirow{3}{*}{$\frac{\text { 地下 }}{0.52}$} & \multirow{2}{*}{\multicolumn{2}{|c|}{$\frac{\frac{\text { 全体 }}{1.68 \mathrm{a}}}{}$}} \\
\hline & 100 & 対照 & & & & & & & & \\
\hline & & 制限 & $0.88 \mathrm{~b}$ & $0.11 \mathrm{c}$ & 0.99 & b 2.94 & $0.08 \mathrm{~b}$ & & & $0.12 \mathrm{c}$ \\
\hline & 30 & 対照 & $14.00 \mathrm{a}$ & $0.53 \mathrm{~b}$ & 14.53 & a 44.81 & $1.08 \mathrm{a}$ & 0.25 & b & $1.33 \mathrm{~b}$ \\
\hline 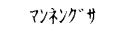 & & 制限 & $0.87 \mathrm{~b}$ & $0.16 \mathrm{c}$ & 1.04 & b 3.10 & $0.08 \mathrm{~b}$ & 0.05 & c 0 & $0.13 \mathrm{c}$ \\
\hline \multirow[t]{6}{*}{ ( S. makinoi) } & 7 & 対照 & $2.89 \mathrm{~b}$ & $0.08 \mathrm{c}$ & 2.97 & b 9.22 & $0.15 \mathrm{~b}$ & 0.03 & c 0 & $0.18 \mathrm{c}$ \\
\hline & & 制限 & $0.83 \mathrm{~b}$ & $0.07 \mathrm{c}$ & 0.90 & b 2.58 & $0.05 \mathrm{~b}$ & 0.02 & c 0 & $0.06 \mathrm{c}$ \\
\hline & 3 & 対照 & $0.06 \mathrm{~b}$ & $0.01 \mathrm{c}$ & 0.07 & b 0.20 & $0.02 \mathrm{~b}$ & 0 & c & 0.02 \\
\hline & & 制限 & $0.02 \mathrm{~b}$ & $0.03 \mathrm{c}$ & 0.01 & b 0.02 & 0 & 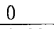 & $\mathrm{c}$ & \\
\hline & 100 & 刘照 & $12.19 \mathrm{~b}$ & $0.96 \mathrm{~b}$ & 13.15 & b 31.05 & $1.00 \mathrm{~b}$ & 0.29 & $\mathrm{~b}$ & $1.29 \mathrm{~b}$ \\
\hline & & 制限 & $0.48 \mathrm{c}$ & $0.05 \mathrm{c}$ & 0.53 & c 1.41 & $0.04 \mathrm{c}$ & 0.02 & d & $0.06 \mathrm{c}$ \\
\hline 峄曰 & 30 & 対照 & $22.51 \mathrm{a}$ & $1.76 \mathrm{a}$ & 24.26 & a 56.53 & $1.71 \mathrm{a}$ & 0.47 & a & 2.18 \\
\hline 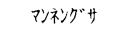 & & 制限 & $1.70 \mathrm{c}$ & $0.19 \mathrm{c}$ & 1.89 & c 4.88 & $0.14 \mathrm{c}$ & 0.07 & c 0 & 0.20 \\
\hline \multirow[t]{6}{*}{ (s.mexicanum) } & 7 & 対照 & $2.00 \mathrm{c}$ & $0.12 \mathrm{c}$ & 2.12 & c 5.04 & $0.18 \mathrm{c}$ & 0.02 & d 0 & 0.20 \\
\hline & & 制限 & $0.86 \mathrm{c}$ & $0.05 \mathrm{c}$ & 0.90 & c 2.18 & $0.05 \mathrm{c}$ & 0.01 & d 0 & $0.07 \mathrm{c}$ \\
\hline & 3 & 対照 & $0.13 \mathrm{c}$ & $0.02 \mathrm{c}$ & 0.14 & c 0.35 & $0.02 \mathrm{c}$ & 0.01 & d 0 & $0.02 \mathrm{c}$ \\
\hline & & 制限 & $0.24 \mathrm{c}$ & $0.03 c$ & 0.27 & c. 0.65 & $0.02 \mathrm{c}$ & 0.01 & d & 0.02 \\
\hline & 100 & 対照 & $7.85 \mathrm{a}$ & $0.86 \mathrm{a}$ & 8.71 & a 22.55 & $0.79 \mathrm{a}$ & 0.33 & $\mathrm{a}$ & $1.11 \mathrm{a}$ \\
\hline & & 制限 & $0.35 \mathrm{c}$ & $0.05 \mathrm{c}$ & 0.40 & c 1.19 & $0.04 \mathrm{c}$ & 0.02 & c & 0.06 \\
\hline 外ゴメ & 30 & 対照 & $6.47 \mathrm{~b}$ & $0.28 \mathrm{~b}$ & 6.75 & b 18.13 & $0.63 \mathrm{~b}$ & 0.15 & b & $0.78 \mathrm{~b}$ \\
\hline \multirow[t]{5}{*}{ (S. oryzifolium } & & 制限 & $0.54 \mathrm{c}$ & $0.06 \mathrm{c}$ & 0.60 & c 1.78 & $0.05 \mathrm{c}$ & 0.02 & c & $0.07 \mathrm{c}$ \\
\hline & 7 & 対照 & $0.03 \mathrm{c}$ & & 0.03 & c 0.08 & $0.01 \mathrm{c}$ & 0 & c & $0.01 \mathrm{c}$ \\
\hline & & 制限 & $0.18 \mathrm{c}$ & $0.01 \mathrm{c}$ & 0.19 & c 0.55 & $0.01 \mathrm{c}$ & 0 & c & $0.01 \mathrm{c}$ \\
\hline & 3 & 対照 & - & - & - & - & - & - & & - \\
\hline & & 制限 & - & - & - & - & - & - & & \\
\hline
\end{tabular}

注2）異なるアルファペット間で5\%水㴖で有意差のあることを走す。(Duncan多重㛟定法) 注2）異なるアルファペット間で5\%水薄で有意着の
注3) - は、枯死したため計測しなかったの。
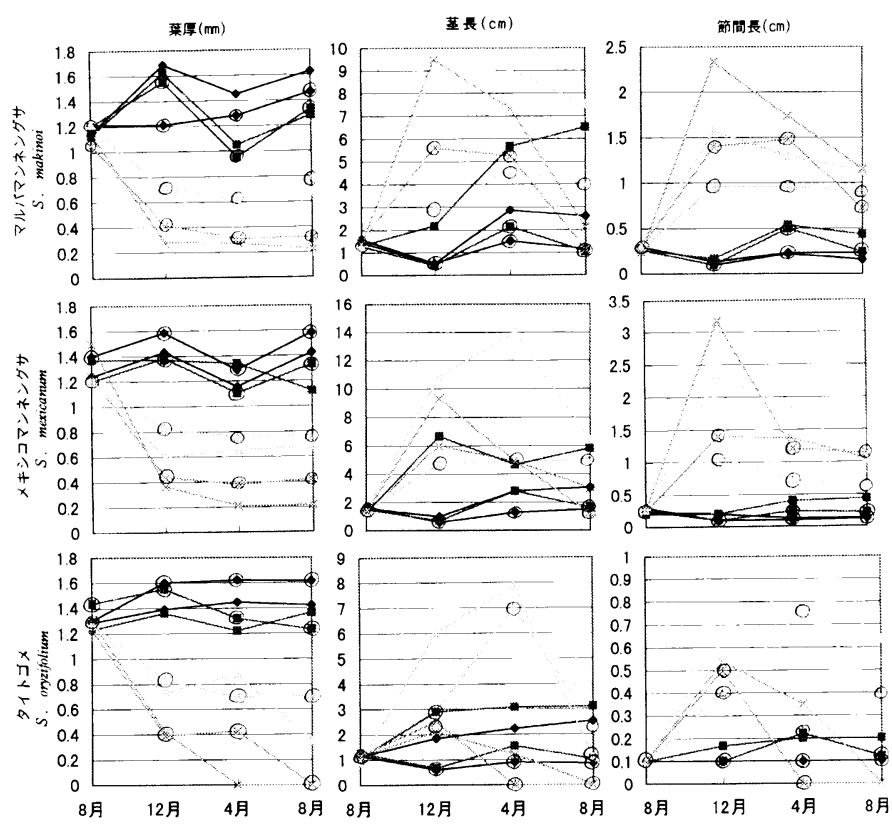

図ー3 相対照度と土㙵量の異なる条件下で生育したSedum 類 3 種の 葉厚, 草丈, 節間長の変化

注）測定値は, 対照土燷区は 3 部位の平均值，土壤量制限区は 5 部位の 平均値を示す。
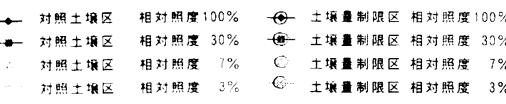
が制限されている方が生育低下の度合が小さい傾向が見られた。

タイトゴメの生体重量の増加比は，無遮光区と相対照度 $30 \%$ 区では，対照土壌区で $22.55 \sim 18.13$ に対して，土㖶量制限区て 1.19 1.78 と抑えられていた。相対照度 7\%区では生体重量が実 験開始時の $4 / 5$ に減少し衰退する傾向であったが，メキシコマ ンネングサと同様に対照土裹区に比較して土壌量制限区の方が生 育低下の度合が小さかった。相対照度 $3 \%$ 区では, いずれむ枯死 した。

（ii）実験期間中の葉数, 茎数, 茎長, 葉厚, 節間長の変化 (図-2, 図-3)

対照土壌区については，マルバマンネングサでは，無遮光区， 相対照度 30\%区でほぼ同様の葉数, 茥数の増加傾向にあったが, 荃長, 節間長については相対照度 30\%区以下では徒長状態を示 した。メキシコマンネングサでは葉数, 茎数が最む増加したのは, 相対照度 30\%区であり，次いで無遮光区，7\%区であり，相対 照度 $30 \%$ 以下では茥長, 節間長の数値も大きく, 明らかな徒長 状態を示した。タイトゴメでは, 無遮光区, 相対照度 30\%区で はほぼ同様に葉数, 茥数が増加したが，7\%区以下での増加は僅 かであった。相対照度 $30 \%$ 以下では茎長，節間長の数値も大き く, 相対照度 $7 \%$ 以下の区では後に枯死した。

土壌量制限区では, いずれの種屯照度条件に関わらず，葉数， 茎数が抑制されたが, 低照度の場合には対照土壌区と同様に, 茎 長や節間長の数値が大きく徒長現象が認められた。対照土壌区, 土壌量制限区共に照度が高いほど節間長が短く, 葉が厚くコンパ クトに生育したが，相対照度 $7 \%$ 以下になると顕著に節間長が長 く, 葉が薄くなり徒長する傾向にあった。

なお，いずれの種類も茎数や葉数は 12 月〜 4 月の低温期（図一 1参照）に最む活発に増加しており，筆者らによるSedum 類は 低温域で最も生育が良好になるという指摘 ${ }^{5}$ を裏付けるものとなっ ている。

\section{(2)人工光における照度と土壤水分の違いによるセダムの生育}

（i）実験終了時の重量 (表一2)

マルバマンネングサでは照度 $20 \mathrm{Klux}$ と $3 \mathrm{Klux}$ の土㙵含水率 50\%区では生体重量の增加比は $6.37 \sim 5.00$ となり, どちらも比 較的生育が良好であったが, 地上部の乾燥重量は 20Klux 区より も3Klux 区の方が少なく，3Klux 下で生育した葉の方が含水率 が高いことが明らかとなった。同照度条件で土堙含水率 25\%区 になると増加比が 2.54 2.81 とやや生育が抑えられた。1Klux 区では，いずれの土㙵含水率区においても増加比 2.8 前後となり 緩慢な生育を示した。0.5Klux 区では，土壌含水率 $50 \%$ で増加 比が 0.91 となり生育は衰退したが，25\%区では 1.57 と極めて緩 慢な生育を示した。0.5Klux 区では土壌含水率 $50 \%$ の場合に, 実験終了時に根腐れを起こしていたこともあり, 地下部の乾燥重 量が著しく小さい值となった。

メキシコマンネングサでは，照度 20Klux の土壇含水率 50\% 区で生育が最も良く増加比は 4.39 , 次いで土壌含水率 $25 \%$ 区の 増加比 2.36 であった。3Klux 区では，いずれの土㙵含水率区で も 1.69 と緩慢な生育であった。1，0.5Klux 区の生体重量は，い ずれの土壤含水率区共に増加比が $0.21 \sim 0.93$ と減少しており, 生育が衰退していた。地上部乾燥重量も生体重量とほぼ相関して いるが，地下部乾燥重量は土壌含水率 50\%，25\%区共に 3，1， 0.5Klux 区では著しく小さな值を示した。

(ii) 葉数, 茎長, 葉厚 $($ 表 -3 )

マルバマンネングサは，照度 20Klux の土壤含水率 50\%区で 葉数は増加比 0.83 , 茥長は増加比 1.05 となっており, ほぼ現状 の形状を維持していた。しかし土壌含水率 $25 \%$ 区では葉数の増 加比 0.59 , 茎長は增加比 0.67 となり, ややコンパクトな形状へ の変化が認められた。3Klux 区は土壌含水率 $50 \%$ 区では葉数の
表一2 異なる土壇水分と照度を組合せた条件下で 3 ケ月間生育

\begin{tabular}{|c|c|c|c|c|c|c|}
\hline \multirow{2}{*}{$\begin{array}{c}\text { 草種 } \\
\text { (学名) }\end{array}$} & \multirow{2}{*}{$\begin{array}{c}\text { 土壌 } \\
\text { 含水率 }\end{array}$} & \multirow{2}{*}{$\begin{array}{c}\text { 照度 } \\
\text { (Klux) } \\
\end{array}$} & \multirow{2}{*}{$\begin{array}{l}\text { 生体 } \\
\text { 重量 }(\mathrm{g}) \\
\end{array}$} & \multirow{2}{*}{$\begin{array}{l}\text { 增加比 } \\
\text { (倍) }\end{array}$} & \multicolumn{2}{|c|}{ 乾燥重量 } \\
\hline & & & & & 地上部 & 地下部 \\
\hline \multirow{8}{*}{ 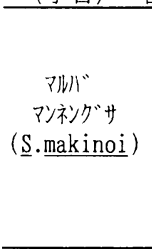 } & \multirow{4}{*}{$\begin{array}{l}50 \\
\%\end{array}$} & 20 & $7.02 \mathrm{a}$ & 6.37 & $0.45 \mathrm{a}$ & $0.16 \mathrm{a}$ \\
\hline & & 3 & $5.75 \mathrm{ab}$ & 5.00 & $0.26 \mathrm{~b}$ & $0.08 \mathrm{bcd}$ \\
\hline & & 1 & $3.79 \mathrm{bc}$ & 2.87 & $0.18 \mathrm{bcd}$ & $0.10 \mathrm{bc}$ \\
\hline & & 0.5 & $0.91 \mathrm{~d}$ & 0.91 & $0.04 \mathrm{~d}$ & $0.04 \mathrm{~d}$ \\
\hline & \multirow{4}{*}{$\begin{array}{l}25 \\
\%\end{array}$} & 20 & $3.28 \mathrm{c}$ & 2.54 & $0.21 \mathrm{bc}$ & $0.13 \mathrm{ab}$ \\
\hline & & 3 & $3.19 \mathrm{c}$ & 2.81 & $0.21 \mathrm{bc}$ & $0.10 \mathrm{bc}$ \\
\hline & & 1 & $2.79 \mathrm{c}$ & 2.78 & $0.16 \mathrm{bcd}$ & $0.12 \mathrm{abc}$ \\
\hline & & 0.5 & $2.18 \mathrm{~cd}$ & 1.57 & $0.11 \mathrm{~cd}$ & $0.07 \mathrm{~cd}$ \\
\hline \multirow{8}{*}{ 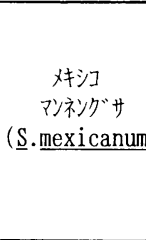 } & & 20 & 6.12 a & 4.39 & $0.37 \mathrm{a}$ & $0.14 \mathrm{a}$ \\
\hline & & 3 & $2.76 \mathrm{~b}$ & 1.69 & $0.14 \mathrm{~cd}$ & $0.02 \mathrm{c}$ \\
\hline & & 1 & $1.34 \mathrm{~cd}$ & 0.93 & $0.07 \mathrm{de}$ & $0.02 \mathrm{~cd}$ \\
\hline & & 0.5 & $0.33 \mathrm{~d}$ & 0.21 & $0.02 \mathrm{e}$ & $0.00 \mathrm{~d}$ \\
\hline & & 20 & $3.67 \mathrm{~b}$ & 2.36 & $0.21 \mathrm{bc}$ & $0.11 \mathrm{~b}$ \\
\hline & 25 & 3 & $2.50 \mathrm{bc}$ & 1.69 & $0.12 \mathrm{~cd}$ & $0.05 \mathrm{c}$ \\
\hline & $\%$ & 1 & $0.75 \mathrm{~d}$ & 0.48 & $0.07 \mathrm{de}$ & $0.02 \mathrm{~cd}$ \\
\hline & & 0.5 & $0.72 \mathrm{~d}$ & 0.49 & $0.10 \mathrm{de}$ & $0.02 \mathrm{~cd}$ \\
\hline
\end{tabular}

注1）照度は、メタルハライドランプ照射下を20Klux区（照度22.666士 $0.478 \mathrm{Klux}$ 、光量子量 $\left.440.57 \pm 3.16 \mu \mathrm{mol} \cdot \mathrm{m}^{-2} \cdot \mathrm{S}^{-1}\right)$ とし、遮光枠を 用いて以下の3区を設定した。

3Klux区 : 照度 $3.130 \pm 0.203 \mathrm{Klux} 、 67.91 \pm 2.37 \mu \mathrm{mol} \cdot \mathrm{m}^{-2} \cdot \mathrm{S}^{-1}$ 1Klux区 : 照度 $1.044 \pm 0.025 \mathrm{Klux} 、 20.79 \pm 2.54 \mu \mathrm{mol} \cdot \mathrm{m}^{-2} \cdot \mathrm{S}^{-1}$

$0.5 \mathrm{Klux}$ 区: 照度 $0.488 \pm 0.054 \mathrm{Klux} 、 10.58 \pm 1.68 \mu \mathrm{mol} \cdot \mathrm{m}^{-2} \cdot \mathrm{s}^{-1}$

注2）人工環境室の設定気温は明期 12 時間 /暗期 12 時間で $25 / 20^{\circ} \mathrm{C}$ 、 湿度は $65 \%$ である。

注3）本実験に用いた黒ぼく土の下層土において、土壤含水率50\%は 飽和容水量に近い湿潤状態に、25\%は永久しおれ点付近の乾燥 状態に相当する。

注4）值は3ポットの平均值を示す。Duncanの多重検定により異なる アルファベット間に $5 \%$ 水準で有意差のあることを示す。

注5）增加比は、実験終了時／挿し木時の値を示す。

\section{表一～異なる土壤水分と照度を組合せた条件下で 3 ケ月間生育} させた後の Sedum の葉数, 茎長, 葉厚

\begin{tabular}{|c|c|c|c|c|c|c|c|}
\hline $\begin{array}{c}\text { 草種 } \\
\text { (学名) }\end{array}$ & $\begin{array}{c}\text { 十壤 } \\
\text { 含水率 }\end{array}$ & $\begin{array}{c}\text { 照度 } \\
\text { (Klux) }\end{array}$ & $\begin{array}{l}\text { 葉 数 } \\
(\text { (枚) }\end{array}$ & $\begin{array}{c}\text { 增加比 } \\
\text { (倍) }\end{array}$ & $\begin{array}{c}\text { 茎 長 } \\
(\mathrm{mm})\end{array}$ & $\begin{array}{c}\text { 増加比 } \\
\text { (倍) }\end{array}$ & $\begin{array}{c}\text { 葉 厚 } \\
(\mathrm{mm})\end{array}$ \\
\hline \multirow{8}{*}{ 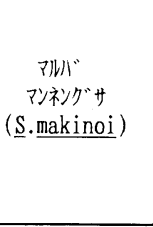 } & & 20 & $115.3 \mathrm{bcd}$ & 0.83 & $30.6 \mathrm{~cd}$ & 1.05 & $1.56 \mathrm{a}$ \\
\hline & 50 & 3 & $162.3 \mathrm{a}$ & 1.28 & $79.1 \mathrm{ab}$ & 3.09 & $1.12 \mathrm{bc}$ \\
\hline & \multirow[t]{2}{*}{$\%$} & 1 & $123.7 \mathrm{abc}$ & 0.83 & $95.4 \mathrm{a}$ & 3.00 & $0.88 \mathrm{c}$ \\
\hline & & 0.5 & $23.0 \mathrm{e}$ & 0.16 & $46.8 \mathrm{ab}$ & 1.81 & $1.14 \mathrm{bc}$ \\
\hline & \multirow{4}{*}{$\begin{array}{l}25 \\
\%\end{array}$} & 20 & $77.7 \mathrm{de}$ & 0.59 & $18.2 \mathrm{~d}$ & 0.67 & $1.32 \mathrm{ab}$ \\
\hline & & 3 & $115.3 \mathrm{bcd}$ & 0.84 & $32.0 \mathrm{c}$ & 1.22 & $1.06 \mathrm{bc}$ \\
\hline & & 1 & $145.3 \mathrm{ab}$ & 1.06 & $66.1 \mathrm{~b}$ & 2.49 & $0.87 \mathrm{c}$ \\
\hline & & 0.5 & $85.7 \mathrm{~cd}$ & 0.56 & $34.0 \mathrm{bc}$ & 1.58 & $0.97 c$ \\
\hline \multirow{8}{*}{$\begin{array}{c}\text { 抽ョ } \\
\text { マンネングサ } \\
\text { (祙.mexicanum) }\end{array}$} & \multirow{4}{*}{$\begin{array}{l}50 \\
\%\end{array}$} & 20 & $220.0 \mathrm{a}$ & 1.96 & $20.8 \mathrm{ab}$ & 0.76 & $1.38 \mathrm{a}$ \\
\hline & & 3 & $132.0 \mathrm{~b}$ & 0.92 & $31.8 \mathrm{a}$ & 1.70 & $0.88 \mathrm{bc}$ \\
\hline & & 1 & $79.7 \mathrm{c}$ & 0.60 & $19.2 \mathrm{abc}$ & 0.73 & $0.68 \mathrm{c}$ \\
\hline & & 0.5 & $24.7 \mathrm{~d}$ & 0.17 & $6.3 \mathrm{c}$ & 0.23 & $0.76 \mathrm{bc}$ \\
\hline & \multirow{4}{*}{$\begin{array}{l}25 \\
\%\end{array}$} & 20 & $200.0 \mathrm{a}$ & 1.53 & $23.6 \mathrm{ab}$ & 0.82 & $1.08 \mathrm{ab}$ \\
\hline & & 3 & $157.0 \mathrm{~b}$ & 1.04 & $28.7 \mathrm{a}$ & 1.12 & $0.89 \mathrm{~d}$ \\
\hline & & 1 & $60.7 \mathrm{c}$ & 0.60 & $14.7 \mathrm{bc}$ & 0.51 & $0.88 \mathrm{bc}$ \\
\hline & & 0.5 & $38.3 \mathrm{c}$ & 0.25 & $12.5 \mathrm{bc}$ & 0.37 & $0.70 b c$ \\
\hline
\end{tabular}

注2）葉厚の測定值は葉身の中央部を計测したもの。

注3）值は3部位の平均値を示す。Duncanの多重検定により異なる アルファベット間に $5 \%$ 水準で有意差のあることを示す。

注4）増加比は、実験終了時／実験開始時の值を示す。

増加比 1.28 に対して, 茎長は増加比 3.09 , 土壤含水率 25\%区て は葉数の增加比 0.84 に対し茎長は増加比 1.22 とやや徒長気味て あった。土襄水分に関わらず，1Klux 区では葉数の增加比 0.83 1.06 に対して, 茎長の増加比 2.49〜3.00, 0.5Klux 区て は葉数の増加比 $0.16 \sim 0.56$ に対して, 茎長の増加比 1.58〜1.81 と著しい徒長状態を示した。

メキシコマンネングサは, 20Klux では土壤含水率 50\%, 25\% 区共に葉数の增加比 1.53 1.96 に対して, 茎長の増加比 0.76 0.82 と減少しておりコンパクトな形状に変化した。3Klux 区では土㙵含水率 $50 \%$, 葉数の増加比 0.92 に対して, 茎長の 増加比 1.70 と徒長が見られたが, 土壤含水率 $25 \%$ では葉数の増 加比 1.04 に対して, 茥長の増加比 1.12 となり形状の変化が少な 
かった。1，0.5Klux 区では土壌含水率 50，25\%区共に葉数，荃 長共に増加比が 1 以下になり衰退する傾向を示した。

両種共に葉厚は，土壌含水率に関わらず $3 ， 1 ， 0.5 \mathrm{Klux}$ 区で は, 20Klux 区の 80〜 50\%と薄くなった。

以上よりマルバマンネングサはメキシコマンネングサよりも若 干耐陰性に優れ，また湿潤条件における地下部への影響す少ない 結果となっており，多湿にも耐えるという指摘 ${ }^{11}$ を裏付けるもの となった。

\section{4. 結論}

Sedum 属数種の生育に及ぼす照度条件と土壤水分条件の影響 について検討した結果, 自然光による相対照度の異なる条件下で の生育反応は，種類によって若干異なり，より生育量が大きくな る照度条件は，マルバマンネングサ，タイトゴメでは無遮光条件 から相対照度 30\%であること，メキシコマンネングサでは，無 遮光条件よりもむしろ相対照度 $30 \%$ であることが明らかとなっ た。いずれの種類も照度が低くなるにしたがって節間長が伸長し たり葉が薄くなり, 徒長する傾向が認められた。相対照度 3\%で は, 本実験の期間内においてマルバマンネングサ, メキシコマン ネングサは衰退傾向を示すすのの生存し，タイトゴメでは枯死す るなど種類による耐陰性の差異が認められた。しかし枯死寸前の 低照度では, 土㙵量が制限されていると, 若干生育低下の度合が 小さくなる傾向が認められた。

人工光による低照度条件下における生育反応については，マル バマンネングサでは，土壌水分条件に関わらず 1 Klux までの低 照度条件下で生育が可能であり，0.5Klux になると土壤含水率 $50 \%$ の湿潤条件では生育の衰退が認められたが，25\%の乾燥条件 であれば衰退せず僅かながら生育を示した。メキシコマンネング
サでは実験期間中，土境水分条件に関わらず $3 \mathrm{Klux}$ では僅かな 生育を示し，1Klux 以下では衰退した。ただし $3 ， 1 ， 0.5 \mathrm{Klux}$ では根部が顕著に衰退していたため生育の持続性が問題である。

以上のように, 屋外の相対照度 $3 \%$ において夕イトゴメのみ枯 死したこと, 人工光の $1 \mathrm{Klux}$ ではメキシコマンネングサは衰退 したがマルバマンネングサは僅かながら生育を示したことから， マルバマンネングサが最も耐陰性に優れることが明らかとなった。 いずれの種す低照度条件になると, 土壤量が制限されていたり乾 燥条件であると衰退が軽減されるなど, 低照度条件に対する反応 は土壤水分状態に影響されることが明らかとなった。

なお筆者らは相対照度の低い条件下でメキシコマンネングサの 葉が偏平状になること ${ }^{9}$, 形状の違いによって葉内の有機酸成分, とりわけリンゴ酸, クエン酸の構成比に違いを示すこと ${ }^{5)}$, さら に節間長が短く, 葉の厚いコンパクトな形状は最も耐乾性に優れ ることを指摘している" 。しかし本研究の結果から, 生育促進を 第一に考えるならば種類によっては遮光条件の方が適すると言え, その現象は筆者らが異なる照度条件下でメキシコマンネングサの $\mathrm{CO}_{2}$ 吸収量を計測した際に直射光下よりも相対照度 $30 \%$ 程度の 方がはるかに高い值となったこと”からも裏付けられる。

Sedum 類は無給水条件下でも貯水機能により長期間の生存が 可能であるが ${ }^{3)}$, 低照度条件であると乾燥適応機構である CAM 型光合成が誘導されないこと ${ }^{6)}$ や本研究に見られた低照度条件下 での形状の変化は, 乾燥耐性を低下させることになると考えられ, 生産時と乾燥条件への導入の際には, 光条件をコントロールする ことによる異なった育成処理が必要であると考えられる。

最後に本実験の実施にあたり，ご協力頂いた阿部篤氏，山岸実 江氏に深謝致します。

\section{引用文献}

1) Bernd W. Krupka (1992): Dachbegrünung: Verlag Eugen Ulmer

2 ）飯島健太郎・近藤三雄 (1992)：多肉植物に よる建築物屋上，壁面の無土壤緑化技術の 開発について:日本緑化工学会都市緑化技 術部会・成果報告会発表要旨第 2 号, $72-75$

3 ）飯島健太郎 (1995): 乾燥条件下におかれた 場合の Sedum 属の水ストレス反応について: ランドスケープ研究 58(5), 69-72

4 ) 飯島健太郎・近藤三雄 (1996) : メキシコマ ンネングサの光合成型ならびに生育に及ぼ す土袞水分之気温の影響 : 東京農業大学農 学集報 41(3)，156-163

5 ）飯島健太郎・馬場直哉・近藤三雄（1996）: 異なる環境条件下で生育したメキシコマン
ネングサの草型の差異と葉内成分について： 第 27 回日本緑化工学会研究発表会研究発表 要旨集, $72-75$

6 ）飯島健太郎・近藤三雄 (1997)：乾燥条件下 におけるメキシコマンネングサの光合成反 応之気温, 照度との関係: 東京農業大学農 学集報 $42(4), 274-286$

7 ）飯島健太郎・近藤三雄（1997）：異なる照度 条件下で育成したメキシコマンネングサの 生育之耐乾性：東京農業大学農学集報 42(4), 287-294

8 ) IIJIMA K., PARK C.H. \& KONDO M. (1997) : Basic research on ecology of ground cover plants of coastal nature and their utilization: Reseach for the Landscape of Waterfront, 87-88
9) 高橋新平・近藤三雄 (1991)：各種グラウン ドカバープランッの日照条件に対する適応 性に関する実験的研究：造園雑誌 54(5)， $161-166$

10）養父志乃夫・中島敦司・河村止（1992）：白 色蛍光灯を光源とする人工日照条件下にお けるグラウンドカバー植物数種の生育に関 する研究 : 日本緑化工学会誌 18(2), 104111

11）湯浅浩史（1970）：セダム属 : 最新園芸大辞 典, 誠文堂新光社, $2522-2549$

Summary: The purpose of this experiment is to clarify the influence of relative light condition on growth response of Sedum (S.makinoi, S.mexicanum, S.oryzifolium). The study evaluated the growth condition of the species using the fresh weight of the plant,numbers of leaf and leaf thickness. Results showed that,elongation growth of all kinds was better in over $30 \%$ relative light intensity. Although elongation growth of $S$. mexicanum was better in $30 \%$ relative light intensity than in full sunlight, the plants grown in full sunlight seemed to acquire high resistance to drought. S.makinoi and S.mexicanum grew under 7\% relative light intensity and growth is less vigorous under 3\% relative light intensity. However S.oryzifolium declined under 7\% relative light intensity and its shade tolerance was inferior. On the other hand,the growth response of Sedum (S.makinoi, S.mexicanum) under combination of soil moisture(wet conditions:0 - $0.05 \mathrm{MPa}$, dry conditions:about-1.5MPa) and light conditions $(20,3,1,0.5 \mathrm{Klux}$ ) was examined. The growth of S.mexicanum is more vigorous under $20 \sim 3 \mathrm{Klux}$ and growth of S.makinoi is more vigorous under $20 \sim 1 \mathrm{Klux}$. S.makinoi declined under wet conditions at $0.5 \mathrm{Klux}$, but degree of decline was restrained under dry conditions. 